Jpn. J. Pharm. Health Care Sci.

\title{
当院の糖尿病治療薬の使用状況と副作用頻度
}

\author{
山崎美保 ${ }^{*} \dagger^{1}$ ，小西敏夫 $\dagger^{1}$ ，前田頼伸 $\dagger^{1}$ ，西園寺真二 $\dagger^{1}$ ，竹田克明 $\dagger^{1}$ ， \\ 福原伸治 $\dagger^{1}$ ，有原章子 $\dagger^{1}$ ，上田玉恵 $\dagger^{1}$ ，突合泉月 $\dagger^{1}$ ，丸橋 $\quad$ 暉 $\dagger^{2}$ \\ 中国労災病院薬剂部 $\dagger^{1}$, 同内科 $\dagger^{2}$
}

\section{Condition for Use of Antidiabetic Drugs and Side Effects}

\begin{abstract}
Miho Yamasaki ${ }^{*} \dagger^{1}$, Toshio Konishi $\dagger^{1}$, Yorinobu Maeda $\dagger^{1}$, Shinji Saionji $\uparrow^{1}$, Yoshiaki Takeda $\dagger^{1}$, Shinji Fukuhara $\dagger^{1}$, Shoko Arihara $\dagger^{1}$, Tamae Ueda $\dagger^{1}$, Satsuki Tsukiai $\dagger^{1}$ and Akira Maruhashi $\dagger^{2}$ Department of Pharmacy $\dagger^{1}$, and Department of Internal Medicine $\dagger^{2}$, Chugoku Rosai General Hospital
\end{abstract}

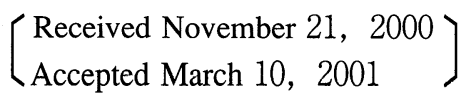

\begin{abstract}
We reviewed the medical charts and conducted a questionnaire survey of 298 outpatients to examine the use of antidiabetic drugs and side effects.

Of the first prescribed medicines, the ratio of Rastinon ${ }^{\circledR}$ (tolbutamide) was the highest and about $90 \%$ were sulfonylureas. At present, $52 \%$ of the prescribed medicines are sulfonylureas, $21 \%$ are sulfonylureas and either an $\alpha$-glucosidase inhibitor or a reducer of insulin resisitance, while $11 \%$ receive insulin.

The side effects of these antidiabetic drugs include hypoglycemia by sulfonylureas or insulin, digestive symptoms due to $\alpha$-glucosidase inhibitor, among others.
\end{abstract}

Keywords — antidiabetic drugs, insulin, BMI, FBS, $\mathrm{HbA}_{1 \mathrm{c}}$, hypoglycemia

\section{はじめに}

糖尿病は生活習慣病の代表的な慢性疾患であり，近年 わが国では糖尿病患者の増加は著しく，その総数は690

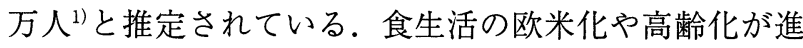
む今日の日本の社会情勢の中で，今後糖尿病人口がさら に増加し, 合併症の発症率が増加することが予測されて いる．糖尿病は生涯にわたり自己管理を必要とする疾患 であるため，我々薬剤師はチーム医療の一員として薬物 療法の支援を行うことが重要であり，より的確な服薬指 導を実践するためには，糖尿病患者の疾病に対する意識 とその現状を把握することが必要であると思われる。

そこで我々は, 糖尿病薬を使用中の当院受診患者の現 状を把握する目的で，当院における外来カルテの調査と 患者自身へのアンケート調查を実施し，糖尿病治療薬の
使用状況および副作用の発生頻度等を調査したので報告 する。

\section{対 象}

当院内科外来を受診している患者のうち，平成 7 年か ら平成 9 年までの 3 年間継続して通院加療中の糖尿病と 診断された298人である。性別は男性160人，女性138人 である。

\section{方法}

対象298人について外来カルテ検索とアンケート調查 を実施し, 年齢分布と初回治療薬, 発症時の肥満指数 (body mass index 以下, BMI と略す) ${ }^{2)}$, 初診時空腹時血 糖値 (fasting blood sugar ( $\mathrm{mg} / \mathrm{dL}$ ) 以下, FBS と略す), $\mathrm{HbA}_{1 \mathrm{c}}$ と治療楽, 低血糖を含む副作用の発生頻度, 合併 
表 1. 糖尿病薬服用中の患者に対するアンケート項目

\section{アンケートにご協力お願いします}

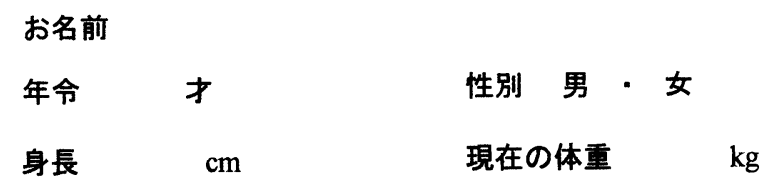

(1) あなたが糖尿病と診断されたのはいつですか。

昭和・平成年 月（約年前）

(2)その時の体重・血糖値はいくらですか。

体重 $\mathrm{kg}$ 血糖値 $\mathrm{mg} / \mathrm{dL}$

現在の体重・血糖值はいくらですか。

体重 $\mathrm{kg}$ 血糖値 $\mathrm{mg} / \mathrm{dL}$

(3) 食事・運動療法を行いましたか。 Yes ・ No

(4) 最初に処方されたお莱は何ですか。

(5) 現在服用されているお薬は何ですか。

(6) 副作用はありましたか。 Yes - No

Yesの方はその時、どのお莱を服用していましたか。

(7) 低血祐になったことはありますか。

Yes - No

Yesの方はその時、どのお薬を服用していましたか。

8) 合併症はありますか。

症の発生状況等について調査した。アンケート調査は, 外来お薬払出空口横に設置してある「お薬相談コー ナー」で患者の同意を得て行った. アンケートの様式を 表 1 に示す.

\section{結果}

\section{1. 対象}

対象患者の現在の年齢を調査したところ，60歳代の患

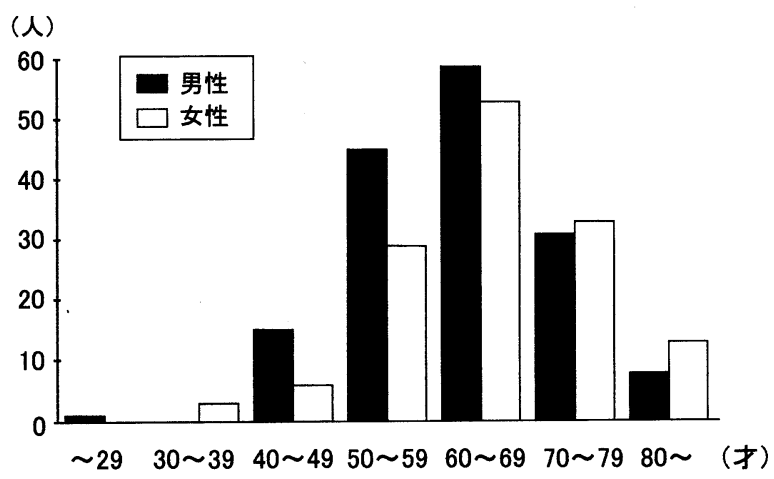

図 1. 対象患者の年齢別分布
者が 112 人で最も多く, 全体の $38 \%$ 占めており，50歳 代から70歳代までが全体の 8 割以上を占めていた（図 1 ). これらの患者の発症年齢を調査したところ, 50歳代 が96人で最も多く，全体の $32 \%$ 占めていた，次いで 40 歳代が75人で $25 \% ， 60$ 歳代が56人で19\%であった（図 2 ）.この結果から, 当院で糖尿病の治療を行っている 患者は，発症時より現在までの罹病期間が約10年の患者 が大半を占めていることがわかった。

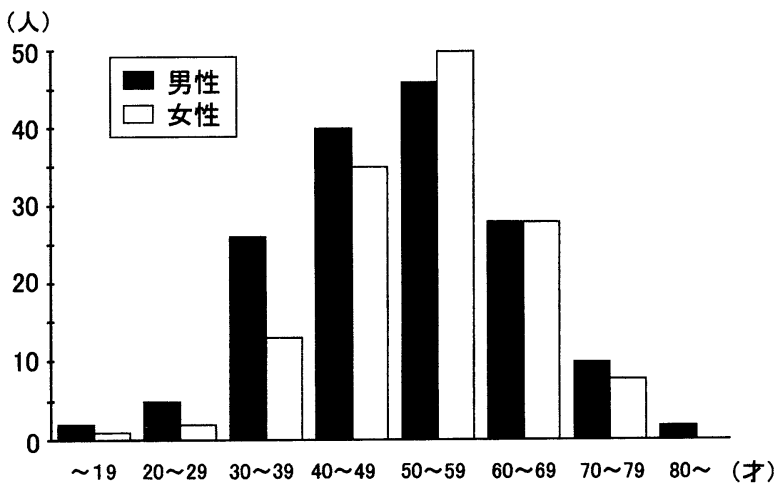

図 2. 発症の年齢別分布 


\section{2. 初回治療薬}

はじめに初回治療薬について検討を行った。原則とし て，食事療法と運動療法を行い，コントロール不良の場 合に薬物療法が開始される。対象298人中，すでに他院 で治療を受けていた患者を除いた無治療例 180 人につい て，初回治療薬の種類と頻度について調査を行った（表 2 ).スルホニル尿素薬（以下，SU薬と略す）の中で比

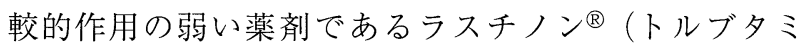
ド）が55\%で最も多く，次にダオニール®（グリベンク ラミド）が24\%となっており，SU薬使用群が全体の 87\%を占めていた.

またFBS別にみた初回治療薬を調査した（表３）. FBS：149mg/dL 以下またはFBS：150〜199mg/dLの症

表 2. 初回治療に用いた薬剤の種類別頻度

\begin{tabular}{|c|c|c|c|}
\hline 薬剂 ${ }^{\circledR}$ & 人数 (人) & 頻度 (\%) & \\
\hline ラスチハン & 99 & 55.0 & \\
\hline グリミクロン & 14 & 7.8 & 86.7 \\
\hline ダオニール & 43 & 23.9 & \\
\hline ベイスン & 17 & 9.4 & \\
\hline ノスカール & 1 & 0.6 & \\
\hline インスリン & 6 & 3.3 & \\
\hline 計 & 180 & 100.0 & \\
\hline
\end{tabular}

例においては SU 薬の中でもラスチノンが高頻度で使用 されており，全体の約 $5 \sim 7$ 割を占めていた。一方 FBS：200〜 249mg/dL または FBS：250mg/dL 以上の症 例においてはラスチノン®に次いで，SU薬の中で比較 的作用の強い薬剤であるダオニールが初回治療薬とし て選択される傾向が高く，全体の約 4 割を占めていた.

\section{BMI}

対象患者 298 人中アンケート調査で算出できた 195 人に ついて発症時の BMI を調査した（図３）。BMI は日本肥 満学会で決められている方法に従って算出し，やせが た：20未満，正常：20-24, やや肥満: 24-26.5, 肥 満：26.5以上の 4 群に分類した。その結果，肥満が 36\%，やや肥満が24\%，正常が33\%，やせがたが $7 \%$ で あった．発症時の体重が標準体重を超えている患者が全 体の 6 割を占めており, 肥満は糖尿病発症要因の一つで あるということを裏付ける結果となった。

そして 4 群に分類した肥満度（BMI）別にみた初回治 療薬を照らし合わせたところ，SU薬は各群において同 割合に使用されていたが， $\alpha$ オ゙ルコシダーゼ阻害薬で あるベイスン®（ボグリボース）ではBMIが高い群にな るほど使用される傾向にあった（表 4 ）.

また治療前後でのBMIの変化を調査したところ，

表 3. 空腹時血糖別にみた初回治療薬剤

\begin{tabular}{|c|c|c|c|c|}
\hline 薬剂 ${ }^{\circledR}$ & $\begin{array}{c}\text { FBS: } 149 \text { 以下 } \\
\text { 人数 (\%) }\end{array}$ & $\begin{array}{c}\text { FBS: } 150 \sim 199 \\
\text { 人数 }(\%)\end{array}$ & $\begin{array}{c}\text { FBS: } 200 \sim 249 \\
\text { 人数 (\%) }\end{array}$ & $\begin{array}{c}\mathrm{FBS}: 250(\mathrm{mg} / \mathrm{dL}) \text { 以上 } \\
\text { 人数 }(\%)\end{array}$ \\
\hline ラスチハン & $34(52.3)$ & $37(66.1)$ & $15(42.9)$ & $13(54.2)$ \\
\hline グリミクロン & $5(7.7)$ & $5(8.9)$ & $3(8.6)$ & $1(4.2)$ \\
\hline ダオニール & $11(16.9)$ & $13(23.2)$ & $13(37.1)$ & $6(25.0)$ \\
\hline ベイスン & $14(21.5)$ & $1(1.8)$ & $2(5.7)$ & $0(0)$ \\
\hline ノスカール & $1(1.5)$ & $0(0)$ & $0(0)$ & $0(0)$ \\
\hline インスリン & $0(0)$ & $0(0)$ & $2(5.7)$ & $4(16.7)$ \\
\hline 計 & 65 & 56 & 35 & 24180 (人) \\
\hline
\end{tabular}

表4.BMI 別にみた初回治療薬剤

\begin{tabular}{|c|c|c|c|c|}
\hline 薬剂 ${ }^{\circledR}$ & $\begin{array}{l}\sim 20 \\
\text { 人数 }(\%)\end{array}$ & $\begin{array}{l}20 \sim 24 \\
\text { 人数 (\%) }\end{array}$ & $\begin{array}{l}24 \sim 26.5 \\
\text { 人数 (\%) }\end{array}$ & $\begin{array}{l}26.5 \sim \\
\text { 人数 }(\%)\end{array}$ \\
\hline ラスチハン & $11(58)$ & $36(54)$ & $25(57)$ & $32(49)$ \\
\hline グリミクロン & $1(5)$ & $4(6)$ & $3(7)$ & $4(6)$ \\
\hline ダオニール & $5(26)$ & $19(28)$ & $11(25)$ & $21(32)$ \\
\hline ベイスン & $0(0)$ & $6(9)$ & $3(7)$ & $7(11)$ \\
\hline ノスカール & $0(0)$ & $0(0)$ & $0(0)$ & $1(2)$ \\
\hline インスリン & $2(11)$ & $2(3)$ & $2(4)$ & $0(0)$ \\
\hline 計 & 19 & 67 & 44 & 65 \\
\hline
\end{tabular}


医療薬学 Vol. 27,No. 3 (2001)

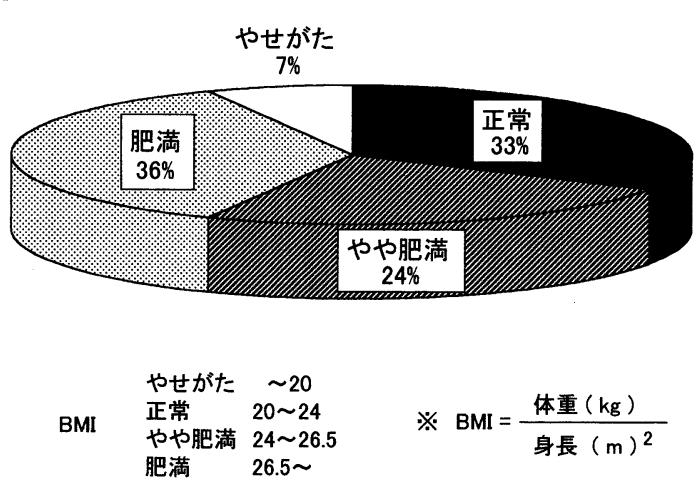

図 3. 発症時の BMI

BMI：24未満のやせがたおよび正常の患者は全体の約 6 割が治療前後で変化が認められなかったが，BMI：24以 上のやや肥満および肥満の患者の60７0\%にBMIの減 少を認めた（図 4 ）。

\section{4. 現在の薬剤使用状況}

さらに現在薬物治療が行われている患者に対して，そ の薬剤の種類と頻度を調査した（表 5 )。当院で治療を 開始した患者では，SU 薬使用群は全体の52\%で初回治 療の $87 \%$ （表 2 ）に比較して大きく減少していた。一方 $\mathrm{SU}$ 薬とべイスン®またはインスリン抵抗性改善薬であ るノスカール (トログリタゾン）の併用例が全体の $21 \%$ 占めており，インスリン使用患者は全体の $11 \%$ で あった。また各薬剤の割合は，当院で治療を開始した患
表 5. 現在服用中の薬剤の種類と頻度

\begin{tabular}{lcc}
\hline \multicolumn{1}{c}{ 薬剂 ${ }^{\circledR}$} & $\begin{array}{c}\text { 当院で治療を開始 } \\
\text { した患者 }\end{array}$ & 全対象者(\%) \\
\hline ラスチノン & $21(11.7)$ & $37(12.4)$ \\
グリミクロン & $19(10.6)$ & $28(9.4)$ \\
ダオニール & $53(29.4)$ & $67(22.5)$ \\
ベイスン & $22(12.2)$ & $27(9.1)$ \\
ノスカール & $3(1.7)$ & $3(1.0)$ \\
SU剤+ベイスン & $27(15.0)$ & $60(20.1)$ \\
SU剂+ノスカール & $11(6.1)$ & $23(7.7)$ \\
インスリン & $19(10.6)$ & $48(16.1)$ \\
その他 & $5(2.8)$ & $5(1.7)$ \\
\hline \multicolumn{1}{c}{ 計 } & 180 & 298
\end{tabular}

者と他院で開始した患者を含む全対象者との間で，大き な差はみられなかった。

また全対象者の $\mathrm{HbA}_{1 \mathrm{c}}$ と現在の使用薬剤を照らし合 わせたところ，SU薬では $\mathrm{HbA}_{1 \mathrm{c}}$ が高くなる程作用のよ り強い薬剂が使用されていた。また $\mathrm{HbA}_{1 \mathrm{c}}$ が10\%以上で は，ダオニール®単独投与，SU薬と $\alpha$ ーグルコシダーゼ 阻害薬の併用，SU薬とインスリン抵抗性改善薬の併用 が多く認められ，インスリンも $42 \%$ と高い割合で使用さ れていた（図 5 ).

\section{5. 副作用の発生頻度と低血糖}

糖尿病の治療中に副作用が発生し，その結果薬剤が中

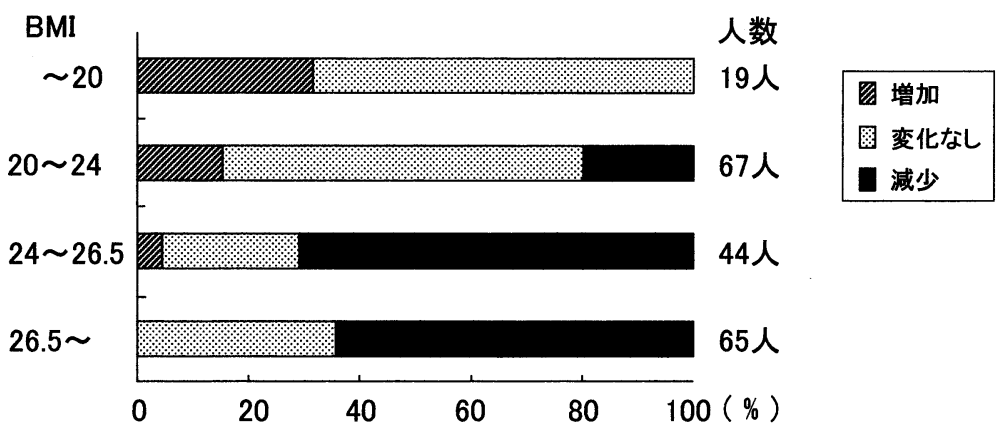

図 4. 治療前後における BMI の変化

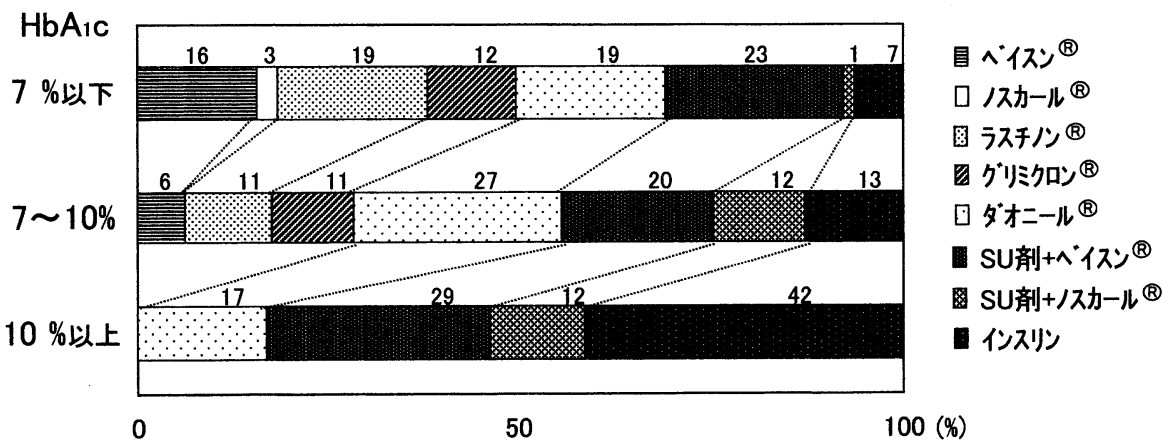

図 5. $\mathrm{HbA}_{1 \mathrm{c}}$ と使用薬剂 
表 6. 副作用の発生頻度

\begin{tabular}{|c|c|c|c|}
\hline 薬剂 $^{\circledR}$ & 全件数 & 件数 & 症状 (人) \\
\hline ラスチノン & 155 & $6(3.87 \%)$ & 低血糖症状(5)，掻痒感(1) \\
\hline グリミクロン & 75 & $1(1.33 \%)$ & 低血糖症状(1) \\
\hline ダオニール & 187 & $17(9.09 \%)$ & 低血糖症状(15), 嘔気(1), 頭痛(1) \\
\hline ベイスン & 140 & $19(13.6 \%)$ & $\begin{array}{l}\text { 腹部膨満(1), 腹部症状(1), } \\
\text { 腹部ガス(2), 下痢(3), 便秘(1), } \\
\text { 発疹(2), 掻棒感(3), 上下肢しびれ(2), } \\
\text { 手足冷却(1), 腸閉塞(1), 低血糖(2) }\end{array}$ \\
\hline グルコバイ & 12 & $10(83.3 \%)$ & $\begin{array}{l}\text { 腹部膨満(2), 食欲増進(1), } \\
\text { 腹部症状(1), 口喝(2), 気分不良(1), } \\
\text { 放屁(2), 発疹(1) }\end{array}$ \\
\hline ノスカール & 39 & $4(10.3 \%)$ & $\begin{array}{l}\text { 肝機能異常(1), 腹部症状(1), } \\
\text { 食欲不振(1), 吐気(1) }\end{array}$ \\
\hline インスリン & 48 & $23(47.9 \%)$ & 低血糖症状(23) \\
\hline
\end{tabular}

止あるいは変更されたケースもある。そこでこれらの副 作用の発生状況を調査した（表 6 ）。 $\alpha$-グルコシダーゼ

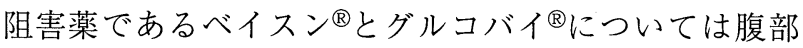
膨満感などの消化器症状が認められた。また当院におけ るノスカールによる肝機能異常が認められた症例は 1 例のみで，薬剤中止により速やかに改善が認められた。

対象298人について低血糖の発生状況をみると, SU 薬で約 $6 \%$ ，インスリン使用患者で約 $50 \%$ に低血糖症状 が認められた．SU薬における低血糖発生要因は錠数の 増量あるいはより作用の強い薬剤への変更によるものが あげられる，その後薬剤の減量や変更が行われた例も あった。

\section{6. 合併症}

糖尿病において合併症の発現は避けることのできない 難しい問題であり，糖尿病の治療とともに合併症の治療
も行われている.この合併症発症の危険因子としては, 罹病期間, 高血糖, 血圧, 遺伝素因が重要であると考え られている，そこで合併症発症の有無と $\mathrm{HbA}_{1 \mathrm{c}}$ との関 連，患者の罹病年数を調査した (表 7$)$. その結果，合 併症は191人に認められ，これは全患者の64\%にあた り, 対象患者の半数以上に何らかの合併症が発症してい たことがわかった.さらにこの表 7 から 50 歳代〜 70歳代 に合併症のある患者が多いことがわかった。またどの年 齢層においても罹病年数が約10年であったが，30歳 代，50歳代～60歳代の $\mathrm{HbA}_{1 \mathrm{c}}$ は $8 \%$ 台と高く，合併症 の存在と一致していることがわかった.

また三大合併症である網膜症，神経障害，腎症と虚血 性疾患 (心疾患, 脳疾患)について調査した。当院におけ る糖尿病患者のうち，網膜症が $41 \%$ ，神経障害が30\%， 腎症の発症率は $5 \%$ であった。また虚血性心疾患の発症 率は15\%，脳疾患は14\%であった（図 6 ).

表 7. 年齢別にみた合併症の有無と $\mathrm{HbA}_{\mathrm{lc}}$ ならびに罹病年数の状況

\begin{tabular}{|c|c|c|c|c|}
\hline 年龄 & $\begin{array}{l}\text { 人数 } \\
\text { (人) }\end{array}$ & $\begin{array}{c}\text { 合併症あり } \\
\text { (人) }\end{array}$ & $\begin{array}{l}\mathrm{HbArc}(\%) \\
\text { 平均値(範囲) }\end{array}$ & $\begin{array}{l}\text { 䍜病年数 (年) } \\
\text { 平均値(範囲) }\end{array}$ \\
\hline $20 \sim 29$ & 1 & $0(0 \%)$ & $5.7(5.7)$ & $9.0(9.0)$ \\
\hline $30 \sim 39$ & 3 & $3(100 \%)$ & $8.9(8.2 \sim 9.9)$ & $10.0(4 \sim 13)$ \\
\hline $40 \sim 49$ & 21 & $11(52 \%)$ & $7.7(5.8 \sim 10.2)$ & $8.9(3 \sim 30)$ \\
\hline $50 \sim 59$ & 75 & $51(68 \%)$ & $8.4(5.5 \sim 13.5)$ & $10.5(1 \sim 30)$ \\
\hline $60 \sim 69$ & 112 & $72(64 \%)$ & $8.0(5.4 \sim 12.0)$ & $12.8(3 \sim 35)$ \\
\hline $70 \sim 79$ & 65 & $43(66 \%)$ & $7.5(5.5 \sim 11.8)$ & $13.3(1 \sim 40)$ \\
\hline $80 \sim$ & 21 & $11(52 \%)$ & $7.6(5.8 \sim 11.0)$ & $14.2(4 \sim 40)$ \\
\hline 計 & 298 & $191(64 \%)$ & & \\
\hline
\end{tabular}



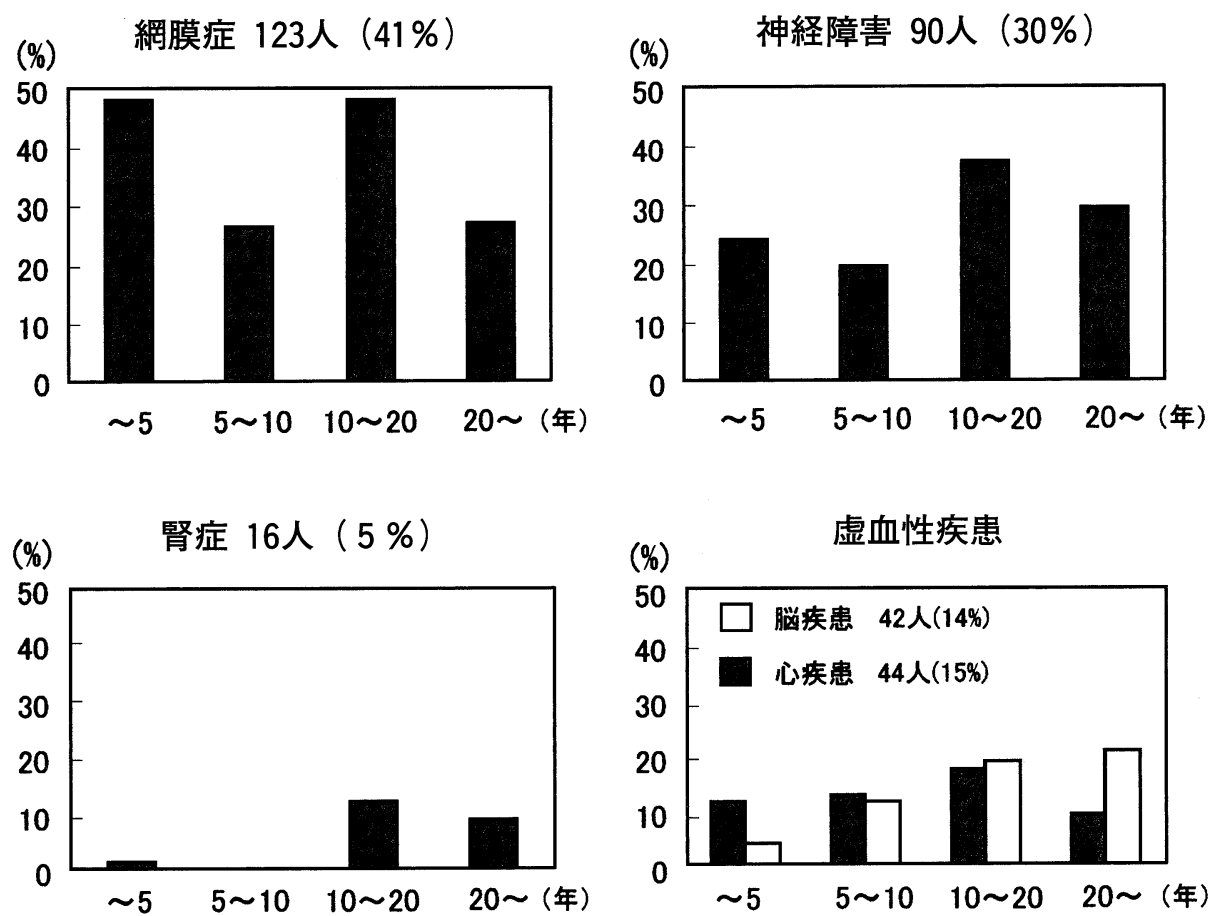

図 6. 罹病期間と合併症の発症頻度

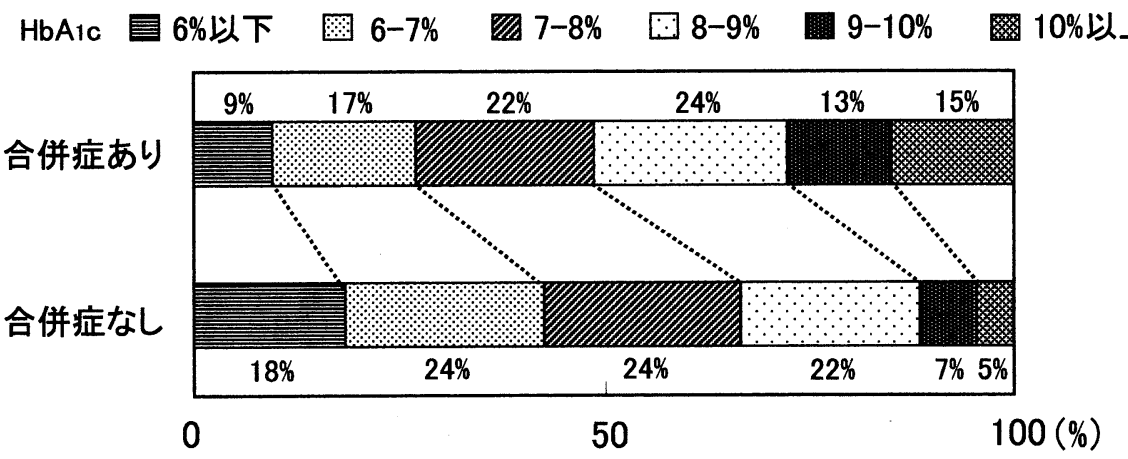

図 7. 合併症の有無と $\mathrm{HbA}_{\mathrm{lc}}$

そこで個々の合併症発症までの期間を調査した（図 $6)$. 一般に罹病期間が,長いほどあらゆる合併症の発生 率が高くなると考えられる，当院における糖尿病患者に おいては, 網膜症, 神経障害について, 罹病期間が 20 年 以上と $10-20$ 年の患者を比較すると，10-20年の患者の ほうがこれらの合併症の発症率が高いという結果が得ら れた。

また合併症の有無と $\mathrm{HbA}_{1 \mathrm{c}}$ の状況を調査した（図 7 ). 合併症の存在する群においては, 存在しない群と 比較して $\mathrm{HbA}_{1 \mathrm{c}}$ は全体的に高くなっており，合併症の 存在する患者のうち $\mathrm{HbA}_{1 \mathrm{c}}$ が $7 \%$ 以上の患者が $74 \%$ 占 めていることがわかった.

\section{考察}

今回我々は, 糖尿病治療薬を使用中の当院受診患者の
現状を把握するために, 当院における外来カルテの調査 と患者自身へのアンケート調査を実施した。 大半の患者 は 2 型であった。

現在, 糖尿病患者の総数は, 厚生省糖尿病実態調査に よると690万人と推定されており，そのうち60歳以上は 365 万人で全糖尿病患者の $53 \%$ 占めている ${ }^{3)}$. 当院に おける糖尿病患者の60歳以上は対象患者の67\%であり， 全国調査と比較して糖尿病に占める高齢者の比率が高い ことが明らかになった。

初回治療薬では, SU薬のラスチノンが約 5 割を占 め, SU 薬全体では約 9 割を占めていた. FBS 別にみて みると，FBS が低いほど SU 薬の中で作用の弱いラスチ ノン®が使用され，高くなるにつれて，作用の強いダオ ニール®が使用される傾向にあった。しかし BMI 別では $\mathrm{SU}$ 薬の割合に違いはなく， $\alpha$ ーグルコシダーゼ阻害薬 
において BMI が高くなる程使用される傾向にあった。 肥満によってインスリン抵抗性が増大した 2 型糖尿病で 有効性が高いと考えられるインスリン抵抗性改善薬（） スカール ${ }^{\circledR}$ : 平成 9 年 3 月発売, アクトス ${ }^{\circledR}$ (ピオグリ タゾン) : 平成 11 年 12 月発売）は，この調査が平成 7 年 から 9 年に行ったものであるため, 初回治療薬としては 1 例しか使用されていない.今後の調査では BMI と何 ら相関のある結果が得られるかもしれない. 初回治療薬 では外来でのコントロールが難しいため, SU薬と $\alpha-$ グルコシダーゼ阻害薬またはインスリン抵抗性改善薬の 併用やインスリン治療へと変化していった。また全対象 者においても薬剤併用やインスリン治療が多く認められ ている。このような薬剤の使用によっても $\mathrm{HbA}_{1 \mathrm{c}}$ が10\% 以上で血糖コントロールが良好でない患者も多く，外来 における血糖コントロールの難しさが示唆された。

厚生省糖尿病調査研究班による慢性合併症の報告 ${ }^{4} に$ よると, 糖尿病受診中の患者約 150 万人のうち, 網膜症 が約 60 万人 $(40 \%)$, 神経障害が約 54 万人 $(36 \%)$, 腎症 が約 16 万人 $(11 \%)$, 虚血性心疾患が約 10 万人 $(7 \%)$, 脳疾患が約 9 万人 $(6 \%)$ と推定されている. 当院にお ける糖尿病患者のうち，虚血性心疾患の発症率は $15 \%$, 脳疾患は $14 \%$ であり, 全国調査による $6-7 \%$ と比較し て発症率が高いことがわかった。このような大血管症は 加齢が極めて重要な危険因子であり, 高齢者糖尿病患者 は網膜症などの細小血管症のみならず，大血管症を合併 した症例が多い. 実際, 厚生省長寿科学総合研究による 老年者糖尿病の長期予後に関する研究3)によると, 高齢 者（60歳以上）糖尿病における大血管症の頻度は $15 \%$ で ある．以上のことから当院における虚血性疾患の発症率 が高いことは，糖尿病患者の高齢者が多いことが影響し
ていると考えられる。またこのことは生活環境も大きく 影響していると考えられる.

糖尿病治療の最終目的は長期罹病後の慢性合併症の発 症と進展を阻止することである，合併症は今日，糖尿病 患者の延命や食事, 運動, ストレスなど社会生活の変化 に伴ってますます重大な状況となってきている，そして 合併症は患者の QOL を著しく低下させ，患者本人の苦 痛をはじめ，家族への心理的，社会的影響は大きい. こ のような合併症の発症予防には，患者及びその家族と医 療スタッフが三位一体となり, 糖尿病の早期より血糖コ ントロールを厳格に保つことが重要であると考えられて いる。また糖尿病治療は糖尿病患者の生活習慣に依存す るところが大きいため, 薬物療法だけでなく医療チーム による患者教育が必要であると考えられる。そして医師 または病棟薬剤師との連携を取り, 患者情報をフィード バックし, 糖尿病治療に貢献することが我々薬剤師の役 割であると考えている．自己管理の手助けができるよう に, 今後も個々の患者に応じた適切な指導に積極的に取 り組んでいきたい.

\section{引用文献}

1)「糖尿病」編集委員会, 糖尿病実態調査の概要 (速 報分)，糖尿病，41，325-331(1998)。

2) 泉寛治, 機能検査 (2) BMI, 体脂肪率, 日本臨床, 56, 515-522(1998).

3）井藤秀喜, “長寿科学総合研究一平成10年度研究報 告”, 厚生省, 東京, 1999.

4）金澤康徳，糖尿病の実態と合併症の脅威一よりょ いコントロールを求めて糖尿病治療をどうする か, 内科, 73, 204-208(1994). 